\title{
Patterns of Disease on Paul Auster’s Timbuktu
}

\author{
Maria Rosa Burillo Gadea \\ Universidad Complutense Madrid, Madrid, Spain
}

\begin{abstract}
Following the theory of Trauma as a critical approach, it is analyzed how Paul Auster' s Timbuktu shows up the maladies of the contemporary world with a parody of disease full of excess and somehow mocking at its own elements. It is a distorted version of infirmity, the way it used to appear in former works of literature. The device is a winkle to the reader to envisage whatever novel or story from a carefully distanced view, very much in the way that Postmodernist authors do but with the realistic use of the form that he regularly employs.
\end{abstract}

Keywords: Trauma, disease, parody, indoctrination, fantasy

\section{Introduction}

Auster's Timbuktu redefines Trauma with the appalling vision of physical infirmity in characters, which is meant to shock the reader. The structure becomes a parody of the great metaphor of disease in literature, which has been traditionally used to express a dramatic state of affairs, and the suffering of human beings in their quest for knowledge or truth. In Auster's world of fiction, facts are no longer what they mean to be, but a distorted vision, the opportunity to rewrite experience in an emotional sense, so as to conjure up the effects.

The focus lays on the decision of characters that far from being free, reproduce the patterns of behaviour which have permeated the culture of the United States. It is also a warning that, whatever election one may hold in life, it becomes a copy of the decisions our forebears made before us. The mocking effect lays on the idea that submission is not only the observation of conventional rules, but it also affects the apparent freedom of vagrancy. The malady lies both on confinement and on following one's own volition, an attitude which has proved no less intoxicating. Auster implicitly asserts that decisions are mainly emotional, ways to escape fear, a device doomed to failure in the long run.

\section{The Parody}

Parody, like other forms of humour, implies a wink to the reader, it relies on the reader's apprehension and response, on the pleasure one takes on sharing the same cultural canvass with the author, and being able to laugh, together with him, at the distorted reality textually reproduced, and indulged. John L. Austin analyzed the meaning of discourse in How to Do Things with Words, and regarded precision as the necessary element to make up felicitous utterances. The thing is that a degree of infelicity or failure is always inherent to whatever utterance, and Judith Butler focusses on the weak points of discourse to construct her Theory of Performativity. She implies that by expressing life with a more abstract vision we are constructing an alternative vias to the generally

Maria Rosa Burillo Gadea, Ph.D. in American Literature, Universidad Complutense Madrid. 
accepted linguistic norm, and the degree of flexibility in using the language, as in Deconstruction, may become a promise. In other words, the addition of distorted and chaotic language into the traditionally accepted norm provides the system with a more flexible tool, it implies freedom, a promise of justice, the possibility of enhancing thought in a better world. In Timbuktu, the mumbling of the thinking dog, Mr. Bones, may be regarded as a good example of the issue.

We are all familiar with the different patterns of disease that literature has evoked to show the malady of existence: Sartre's Nausea, Camus's Peste, Gide's L'inmoraliste, or Port's malady in The Sheltering Sky, by Paul Bowles, his existencialist response to life, to name only a few. The most impressive metaphor for disease is perhaps Thomas Mann's election of a tuberculosis sanatorium in The Magic Mountain, which shows up a world reduced to physical infirmity, confined as his protagonist, Hans Castorp. Auster pursues the issue, and makes a parody of the effects that such a book may have had in the innocent and naive Willy Christmas with the healthy purpose of showing the imprint that outstanding pieces of literature have imposed upon us. It is a warning to the intoxication of a system where myths have proved a more soundful reality than life itself. The parody cautions on the degree of indoctrination that we all suffer for having read books. And it is meant as an afterthought and utter reflection on the nature of tales such as we have been told: "The national media...make conspiracism essential to an understanding of history and society” (Goldberg, 2001, p. 243).

Auster's narrative relies entirely on fantasy, on the farce itself, and for the fun of it. It is a warning to believers, romantics, or idealists, in the subtle hope of making them aware of the trick beneath ideology. The description of Willy's physical illness is an obvious distortion of Hans Cartorp's, and it is also a sign to readers on the implications that a life meant for honour must endure. The suffering is appalling and nauseating. Even when the point is on the fabulous, Auster implicitly cautions on patterns of behaviour inmersed in mysticism, on the danger of leading honorable lives at the higher cost of sacrificing one's own existence, mocking then at the idea of sacrifice itself.

Western civilizations have typically made use of the jeremiad writing as the marrow-bone basis for plots. It is a structure based on the idea that the conflict of the trama becomes ultimately solved through the necessary process of captivity, and then, recognition of guilt, either social or collective guilt, expiation through sacrifice and recovery. The pattern has been used in detective stories to acknowledge social guilt, and also in the genre of horror to conjure up remorse and individual guilt.

Auster makes use of the same structural plot, and his novel Travels in the Scriptorium (2007) makes it even more evident. In Timbuktu there is captivity in both Willy Christmas and Mr. Bones, but, unlike regular fiction, there is no plausible solution, and neither of them is mentally or physically restored despite the sacrifice, their personal trauma expressed through illness. On the contrary, the author seems to suggest that whatever election in life is definitely pointless, it is not restorative, and it only asserts irrational patterns of existence. Both Willy and his dog have chosen an emotional response, and the reader acknowledges that theirs has been in fact a useless pursuit, a waste of their lives, since the next minute they are off, they do not exist any more. An enormous silence is then installed. This is Auster's particular response to the theory of Trauma (Harpham, 2005, 2008; Vickroy, 2002), a distortion meant to show the unrootedness of contemporary world. As Jameson observes: “[...] never in any previous civilization have...the fundamental questions of being and of the meaning of life, seemed so utterly remote and pointless” (Jameson, 1971, p. xviii). 
While Willy Christmas defends his right to lead a singular existence, the thinking dog doubts on being practical or else, letting himself be guided by illusion, the dream of reencountering his master in a better world, Timbuktu, the promise to come. Somehow the reader feels that they have been deluded, that life has deceived them both, and this is the startling point, that honorable decisions become useless, or definitely bound to failure. A practical option is neither plausible, and Mr. Bones's surrender to comfortable family life, beautiful house, and the suburbian environment does not prevent the dog from being on a lead. The very foundations of marriage and sweet home have given way to lack of communication and lies. At this point Nature, like the dog himself, is figuratively taken on a lead, marred, confined.

Willy Christmas is the son of a Jewish family who has emigrated to the United States, running away from the menace of the European War. The evidence of trauma shows. While Willy's mother attitude is a withdrawal from society, Christmas asserts his right to freedom, and he embraces vagrancy instead. He sympathizes with the romantic concept of travelling, thus becoming a wanderer followed by his dog, Mr. Bones. His behaviour is reminiscent of Kerouac's On the Road, and of the angellic figure of the criminal in Capote's On Cold Blood, who represents the American dreamer, a revised version of Cooper's Natty Bumppo. The spirit of the American hero prevails, then we learn that Willy may be a paranoid, and therefore not to be trusted at all. Such is the irony, the wink to the reader, the metafictional game as an end in itself. And it is laid in the form of a hieroglyph with the healthy aim that readers may draw their conclusions: "A fantastic mode, structured upon contradiction, upon 'impossibility', becomes a disturbingly appropriate medium [...] to represent the fullness and emptiness of secularized culture" (Jackson, 1998, p. 170).

The novel thus becomes a fabrication, the kind of stuff that dreams are made of as Shakespeare would say, and the story becomes art without false pretensions, further transcendency or truth, in the words of Holzapfel: “[Auster] [...] causes the novels to extend past their conventional bounds onto a metafictional level” (Holzapfel, 1996, p. 110). We are concerned with fantasy, and the same is true of Auster's other arguments, The New York Trilogy (1988), Mr. Vertigo (1995), or The Book of Illusions (2002), to name only a few:

Auster's fiction incorporates many unreal or unearthly places $[\ldots]$ spaces of imagination $[\ldots]$ intended by their creators to act as a refuge from the cruel practices of the world beyond their boundaries. Places constructed entirely within the realm of the imagination... (Brown, 2007, p. 129)

It is in fact fantasy for the sake of it, or as Rosemary Jackson would say: "[...] an overt violation of what is generally accepted as possibility” (Jackson, 1998, p. 14) meant for fun, realization, and perhaps a promise of enhancing the world with alternative ways and possibilities.

\section{Indoctrination}

Auster mocks at the very fact of writing when Willy, a talented author, knowing that he is about to die goes on search of his school teacher, in order to give her his manuscript, his tales to the world so as to say. Instead he finds the house of Edgar Allan Poe, a resemblance to whom he is personally indebted, we assume, when a new seizure takes hold of him, and makes us, readers, aware of his death. The trick mocks at characters and readers alike, and the narrator takes hold of the story cutting short the final drama. Being obvious enough, there is no need to pursue the issue any further. The artifice thus becomes evident as an afterthought. Rather than sympathizing, readers feel puzzled on the anecdotes of Willy's life. Will is the visionary who finds a sense to life on Christmas 
time, his search an imitation of Father Christmas, and the tattooing of a Santa the further irony to show how extensively we all have been fooled. Indoctrination, catechism is made explicit, and there is also evidence on Willy's mother's apprehensions that his son will be denied a Christian burial as he has mutilated his body, and altered it. There lays the irony, the brain appeal, the awe.

The very idea of sacrifice for redemption is then ridiculed, and we are furtherly driven to perplexity and fun. The spell of love, idealism, and religion is explored and altered in a farsical way, allowing the necessary room for fantasy, and priorizing it as foremost. "Fiction reigns”, as Chénetier would say (Chénetier, 1997, p. 328), and Michel Contat states how Auster leans on to fables to avoid sentimentalism: "You crossed out everything that was too sentimental and too moving” (Auster, 1996, p. 187). The whole point comes to a climax when we are informed that Willy Christmas has given away all the money that he inherited from his mother, when he might have used it for his own sake, and for the care of his dog. Then the action raises to parody, and his existence has become pointless and subdued.

Next time the focus is on poor Mr. Bones, and there is an emphasis on the vacuum, his feeling of emptiness, his longing for protection. Despite the wise condition of his mind-he is able to think, and mumble the language of humanity - we are now and then reminded of his shortcomings as a dog. Auster has chosen him to be the main character of the narrative, and he provides him with the gift of doubt, he has a thinking mind alright. Unlike Willy Christmas who is just a visionary, Mr. Bones has a condition for judging, and that makes him a more interesting character altogether.

For one reason he chooses submission and the safety of a home in order to survive in a difficult world, and then he feels captive, again the jeremiad plot. Captivity is regarded upon its different nuances. He feels happily and willingly in prison for the love of his master. This is an emotional election, and despite discomfort he is willing to take it. He allows enclosure for the Chinese boy, and he remains captive on a lead in the suburb, every time the head of the family is at home. As the argument proves his is also an emotional response, even when it is meant for safety and survival, his decisions are equally wrong.

Mr. Bones's life's options have been compared with the contrasting attitudes evident in Don Quijote and Sancho. Mr. Bones is being a Sancho, his is a practical quest, but we also feel that every time he is making an emotional choice. There is mainly tenderness in the election of a dog as a main character of the narrative, and this figure allows for the reader sympathy and passion, the kind of homeliness that Edgar Allan Poe speaks of, a main proof that the story will be commonly shared by the reading public, and then, the final demonstration that a touching plot is the everlasting key to emotions. All this is finally implicit and proved.

As the farce develops, we are confronted with the irrational option of Mr. Bones's decision. He becomes a Quijote, then, an overt violator of rationality and common sense, but then we are faithfully reminded that he is just a dog. Auster restates the futility of his final action, the very same argument pointed on his essay to Kafka:

He wanders towards the promised land [...] And yet on this road he is never free. For all he has left behind still anchors him to his starting place, makes him regret ever to have taken the first step, robs him of all assurance in the rightness of departure. (Auster, 1992, p. 23)

In dreams Willy Christmas has spoken to his dog, and has inoculated in him the illusion of regaining paradise, his own Timbuktu, a wonderful momentum where not all dogs, but some selected dogs are allowed. The 
anecdote implies the parody of Puritanism, it involves Predestination, and the dogma of the very few Chosen for salvation. There remains implicit the belief that we are all predetermined, and conversion, a vision of faith, a new awakening, reminiscent of Jonathan Edwards's, shows the way to Paradise:

When the time comes for you to go to Timbuctu.

You mean dogs are allowed?

Not all the dogs. Just some. (Auster, 1999, p. 181)

The argument is that irrationality prevails, and captivity in absence of a master is not a restorative force. But then, it is an argument posed by a dog, and as such, emotionally crippled.The implications are made evident, he is virtually handicapped for fear of the vacuum, as humans may be. We are faced with what Eagleton's theory of The Holy Terror (Eagleton, 2005):

What was a poor dog to do? [...] Every thought, every movement, every particle of the earth and air was saturated with Willy's presence. ... it was more than just love or devotion that caused Mr. Bones to dread what was coming. It was pure ontological terror. Subtract Willy from the world, and the odds were that the world itself would cease to exist. (Auster, 1999, p. 4)

There is always the counter-argument that wider knowledge would have coped with the problem of solitude, and instruction might have provided the thinking dog with a more soundful position in life, and this is the real dream, the echo of the narrative as it is transmitted to readers, the moment when emotional intensity surpasses the limits of the farce, and then the double game that it may only represent the viewpoint of the paranoid Willy Christmas. Further thoughts interlace the gambling arguments of story telling, coming back and forth as an afterthought:

[...] you would have achieved far greater things than that, Mr. Bones.You had the head of it, you had the will, you had the guts [...] I should have given you a try, refused to take no for an answer. Only out of stubborness are great things born. Instead, what did I do? I dragged you out to Uncle Al's novelty shop in Coney Island, that's what I did [...] I should have given you a chance to reach the stars... the truth is, my friend, that dogs can read. (Auster, 1999, pp. 84-85)

The poet at Timbuktu might have been Celan, a victim at the Second World War, a survivor at the concentration camps, who will be finally driven to suicide. Auster is equally pesimistic upon the benefit of knowledge or art: " $[\mathrm{He}][\ldots]$ push his life into the void in order to cling to his identity. It is an impossible struggle, doomed from the start to disaster. For poetry cannot save the soul o retrieve a lost world” (Auster, 1992, p. 94). And then, as Vickroy (2002) argues the very act of writing displays evidence of its restorative force.

In Auster's world fiction shows the disenchantment of an author who has given up his quest for father figures, the necessary surrender to the facts of existence: "I think all my father figures are dead. Everyone has died now” (Auster, 1996, p. 186). All in all, one may safely argue that the story’s concern with emotions beyond entertainment suggests some sort of acknowledgement on the condition of human beings and motivation. The text, intertextual and all, suggests further assumptions for those other spaces of the imagination, and this is always welcome, and allowed.

\section{Conclusion}

Very much like the rest of Auster's fiction, Timbuktu aims at fantasy. His is a postmodern approach. The focus of the argument is on presenting a distorted vision of reality. It explores the submission to cultural patterns 
deeply engrained in the collective memory. Romanticism, Puritanism, even convention as dogma are interpreted as emotional pursuits of the mind, and the very idea of choosing a dog as a main character is a trick appealing to the reading public, a maneuver to raise its emotional response, the kind of passion and homeliness suggested by Edgar Allan Poe. Thus the final parody relies on effect upon the reader, which has also been cheated, moved by the naiveté of the thinking dog. It shows that there are echoes of Trauma in every reader involved, and one's own reaction to infirmity, despite its being deliberately exaggerated, is a main proof, the final awareness to conjure up the effects of short vision, narrowmindedness and strictness. We have been fooled. It is a final mocking effect on us all.

\section{References}

Auster, P. (2007). Travels in the scriptorium. New York: Henry Holt and Company.

Auster, P. (2002). The book of illusions. London: Faber and Faber.

Auster, P. (1999). Timbuktu. London: Faber and Faber.

Auster, P. (1992). The art of hunger. Essays. Prefaces. Interviews. Los Angeles: Sun \& Moon Press.

Auster, P. (1987). The New York trilogy. London: Faber and Faber.

Auster, P., Contat, M., \& Waters, A. (1996). The manuscript in the book: A conversation. Yale French Studies, No. 89, Drafts, 160-187. New Haven: Yale University Press.

Brown, M. (2007). Paul Auster. Manchester and New York: Manchester University Press.

Butler, J. (1996). Excitable speech: A politics of the performative. New York: Routledge.

Chénetier, M. (1997). Más Allá de la Sospecha. La Nueva Ficción Americana desde 1960 hasta Nuestros Días (Beyond suspicion. The new American fiction since 1960 up to the present). Madrid: Visor.

Eagleton, T. (2005). The holy terror. New York: Oxford University Press.

Goldberg, A. (1998). An interview with professor Dominick LaCapra. New York: Cornell University. Retrieved from http://www.yadvashem.org

Goldberg, R. A. (2001). Enemies within: The culture of conspiracy in modern America. New Haven, CT: Yale University Press.

Harpham, G. (2005). Beneath and beyond the "crisis in the humanities”. New Literary History, 36(1), 21-36.

Harpham, G. (2008). The Human and the Humanities. Wake County Physician Magazine, 14(4), $26,35$.

Holzapfel, A. (1996). The New York trilogy: Whodunit? Tracking the structure of Paul Auster's anti-detective novels. Frankfurt: Peter Lang.

Jackson, R. (1998) Fantasy. The literature of subversion. New York: Routledge.

Jagger, G. (2008). Judith Butler: Sexual politics, social change and the power of the performative. New York: Routledge.

Jameson, F. (1971). Marxism and form. Princeton: Princeton University Press.

LaCapra, D. (1998). History and memory after Auschwitz. Ithaca, NY: Cornell University Press.

Salih, S. (Ed.). (2002). Butler, Judith: Essential guides for literary studies. New York: Routledge Critical Thinkers.

Vickroy, L. (2002). Trauma and survival in contemporary fiction. Charlottesville: University of Virginia Press. 